\title{
Penerapan Model Pembelajaran Perubahan Konseptual Dengan Teknik Analogi Penghubung Dalam Pembelajaran Fisika Untuk Meningkatkan Pemahaman Konsep Siswa Kelas VIII SMP Swasta Diakui Adhyaksa 2 Kupang
}

\author{
Amiruddin Supu ${ }^{1}$, Josua B. Mowata ${ }^{2}$, Yusniati H. Muh. Yusuf ${ }^{3}$ \\ ${ }^{1,2,3}$ Program Studi Pendidikan Fisika, FKIP, Universitas Nusa Cendana
}

Amiruddin Supu, Dosen Program Studi Pendidikan Fisika, FKIP Undana;

E-mail: amirsupu@yahoo.com
Abstract: The kind of this research is experiment research that have purpose to know well there is the differences of concept unnderstanding between students who are teached by used conceptual changing learning model with bridging analogy technique with student who are teached by use conceptual changing learning model with anomaly technique.

The population of this research is student class VIII at SMP swasta Diakui Adhyaksa 2 Kupang with the sample are Calss VIII A as experiment class or students who are teached by use conceptual changing learning model with bridging analogy technique and control class is VIII B that consist of student who are teached use conceptual changing learning model with anomaly technique.

Based on data analysis use t- test where first hypothesis use two tail test, and second hypothesis use right right tail test. For the first hypothesis show that $t$ count $=4,968859$ and $t$ table $=1,9151$ with significant level $(\alpha)=0,05$ and fre degree $(d k)=36$. Because of $t$ count $=4,968859>t$ table $=1,9151$ so, zero hypothesis $(\mathrm{HO})$ is denien and first hypothesis is accept. This means that there is differences of concept understanding of learning physic between students who are teached use conceptual changing learning model with bridging analogy technique with students who are teached use conceptual changing learning model with anomaly tecnique. And second hypothesis show that $t$ count $=4,968859$ and $t$ table $=1,68026$ with significant level $(\alpha)=$ 0,05 and fre degree $(d k)=36$. Because of $t$ count $=4,968859>t$ table $=$ 1,68026 so, zero hypothesis (HO) is denien and first hypothesis is accept. This means that student's physic's concept understanding of students who are teached by use conceptual changing learning model with bridging analogy technique more high than students who are teached by use conceptual changing learning model with anomaly tecnique.

Keywords: Changing Concept Learning Model, Bridging Analogy, Concept Understanding

Abstrak: Penelitian ini adalah penelitian eksperimen yang bertujuan untuk mengetahui adanya perbedaan pemahaman konsep fisika yang signifikan antara siswa yang diajar menggunakan model pembelajaran perubahan konseptual dengan teknik analogi penghubung dengan siswa yang diajar menggunakan model pembelajaran perubahan konseptual dengan teknik anomali.

Populasi penelitian adalah siswa kelas VIII SMP Swasta Diakui Adhyakasa 2 Kupang dengan sampel penelitian terdiri atas kelas eksperimen (kelas VIII A) atau siswa yang diajar menggunakan model pembelajaran perubahan konseptual dengan teknik analogi penghubung dan kelas kontrol (kelas VIII B) model pembelajaran perubahan konseptual dengan teknik anomali.

Dari hasil analisis data penelitian menggunakan uji t. Uji hipotesis pertama menggunakan uji dua pihak, sedangkan uji hipotesis kedua menggunakan uji t 


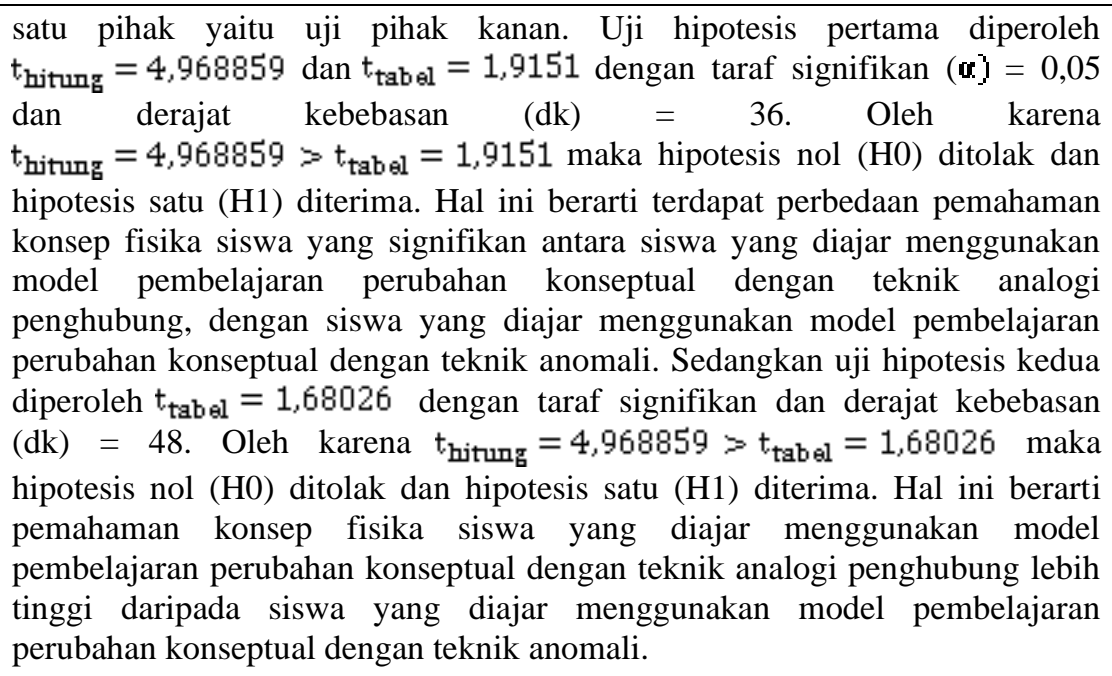
pembelajaran perubahan konseptual dengan teknik analogi penghubung lebih tinggi daripada siswa yang diajar menggunakan model pembelajaran perubahan konseptual dengan teknik anomali.

Kata kunci: Model Perubahan Konseptual, Teknik Analogi Penghubung, Pemahaman konsep

\section{Pendahuluan}

Fisika adalah bidang ilmu yang merupakan bagian dari rumpun ilmu pengetahuan alam, memiliki ciri yang terkenal yaitu sarat akan konsep -konsep yang abstrak. Dengan demikian mengajar fisika memiliki tantangan tersendiri bagi guru dalam kegiatan pembelajaran. Hal ini karena konsep yang diajarkan bersifat abstrak serta pembahasaannya sangat ilmiah sehingga konsep fisika dirasakan baru dan sulit dipahami oleh siswa yang pembentukan pola pikirnya masih dalam tahap perkembangan. Meskipun demikan, siswa sebenarnya telah memiliki potensi yang baik untuk memahami konsep yang diajarkan. Suatu hal yang sering diabaikan guru adalah adanya pra-konsep atau (konsepsi alternatif) dalam diri siswa yang diperolehnya baik dari buku bacaan yang mereka baca, dari pembelajaran sebelumnya, maupun dari fakta yang mereka temui dalam kehidupan mereka sehari-hari. Dalam kegiatan pembelajaran gejala tersebut sering muncul. contohnya ketika siswa diberikan pertanyaan secara klasikal tentang konsep yang diajarkan, siswa cenderung memiliki jawaban yang bervariasi. Biasanya guru langsung secara ekstrim menolak setiap pandangan siswa dengan menggambarkan kebenaran secara ilmiah tentang jawaban pertanyaan tanpa adanya kepedulian terhadap jawaban yang diberikan siswa. Hal ini dilakukan guru cukup beralasan karena konsep alternatif yang dimiliki siswa sering bertentangan dengan konsep ilmiah yang diajarkan. Namun sebenarnya konsep alternatif yang dimiliki siswa dapat menjadi jembatan yang baik untuk mencapai konsep secara ilmiah.

Pandangan konstrukstivisme menjelaskan bahwa informasi baru masuk ke dalam diri masuk melalui dua mekanisme, yaitu akomodasi dan asimilasi. Pada proses akomodasi, struktur kognitif dapat menyerap informasi baru yang sedang dihadapi melalui suatu proses memodifikasi struktur yang ada atau pembentukan skemata baru. Sedangkan pada proses asimilasi, proses beradaptasi dengan informasi baru yang datang dari lingkungannya atau proses adaptasi dengan masalah, seseorang menggunakan kemampuan dan struktur kognitif yang sudah ada. Ketidak seimbangan (disquibrium) dalam struktur kognitifnya yang dialami seseorang, disebabkan ketidaksesuaian antara informasi baru yang dihadapi dengan struktur kognitif yang dimiliki. Dalam kondisi seperti ini orang akan berusaha untuk mereorganisasi struktur kognitifnya agar sesuai dengan informasi baru yang dihadapinya karena ia menyadari bahwa cara berpikirnya bertentangan dengan kejadian yang ada disekitarnya, (Darma dalam Kusdian, 2009:6).

Dalam menerapkan model pembelajaran perubahan konseptual pada kegiatan pembelajaran, diperlukan sarana penunjang baik itu metode, media, dan teknik . Teknik analogi penghubung (bridging analogy) adalah salah satunya. Teknik 
analogi penghubung (bridging analogy) dipahami sebagai model penjelasan yang dapat memudahkan siswa memahami materi secara baik. Konsep yang dipelajari diperkenalkan kasus analoginya dengan obyek keseharian atau fenomena sekitar yang dikenali siswa kemudian diperkenalkan kasus analogi penghubung yang dapat menghindari salah konsep dan menumbuhkan pemahaman secara mendalam tentang konsep yang dipelajari.

Brown dan clement (Irawati, 2011:4) menyatakan bahwa teknik analogi penghubung (bridging analogy) memiliki langkah-langkah operasional sebagai berikut: (1) Pendeteksian miskonsepsi (2) Memperkenalkan kasus analogi (3) Pemetaan (4) Pemilihan analogi penghubung (bridging analogy). Analogi penghubung membuat jarak antara analogi dan materi yang dianalogikan menjadi dekat. Atau dengan kata lain analogi penghubung (bridging analogy) membagi analogi menjadi 2 langkah yang lebih pendek yang memungkinkan siswa lebih mudah menangkap dari pada satu langkah yang jauh.

Model perubahan konseptual dengan teknik analogi penghubung dalam pembelajaran, didesain dengan orientasi pembelajaran bertemakan perubahan konsep. Hal ini merujuk dari fenomena belajar dimana siswa telah memiliki konsepsi yang cenderung miskonsepsi sehingga perubahan konsep dilakukan dengan melibatkan analogi sebagai media negosiasi pemahaman untuk terjadinya perubahan konsep dari konsep konsepsi yang tidak ilmiah kepada konsep yang bersifat ilmiah. adanya perubahan atau peningkatan perbendaharaan konsep ilmiah dalam diri siswa inilah yang dipahami sebagai peningkatan pemahaman konsep.

\section{Metode Penelitian}

\section{Tempat dan Waktu Penelitian}

Penelitian ini dilaksanakan di SMP Swasta Diauki Adhyaksa 2 Kupang kota kupang bulan september sampai oktober 2014

2. Jenis dan Desain Penelitian

Penelitian ini merupakan experimental research dengan variabel dalam penelitian ini adalah penerapan model pembelajaran perubahan konseptual dengan teknik analogi penghubung, variabel terikatnya adalah pemahaman konsep siswa yang dilihat dari hasil tes pemahaman konsep siswa.

3. Populasi Penelitian dan sampel penelitian
Yang menjadi populasi dalam penelitian ini adalah semua siswa Kelas VIII SMP Swasta Diakui Adhyaksa 2 Kupang pada tahun pelajaran 2014/2015 Sampel dalam penelitian ini diambil dengan cara random sampling dengan menetapkan dua kelas sebagai sampel dari kelas VIII SMP Swasta Diakui 2 Kupang yaitu kelas yang satu sebagai kelas eksperimen dan kelas yang lain sebagai kelas kontrol didasarkan pada asumsi populasi adalah homogen.

4. Prosedur penelitian

Prosedur dalam penelitian diawali dengan tahap persiapan yang meliputi penyusunana perangkat pembelajaran beserta instrumen yang nantinya dipakai dalam penelitian. Tahapan pelaksanaan perlakuan yang diawali dengan tes kemampuan awal siswa kemudian dianjutkan dengan melakukan perlakuan dengan menerapkan model pembelajaran perubahan konseptual dengan teknik analogi penghubung untuk kelas eksperimen sedangkan pada kelass kontrol diterapkan model pembelajaran perubahan konseptual dengan teknik anomali. Tahap ahir prosesdur adalah dengan pemberian tes pemahaman konsep diakhir perlakuan pada kelas kontrol dan kelas eksperimen.

5. Pengumpulan Data

Data yang akan dikumpulkan diperoleh melalui Tes pemahaman konsep dalam bentuk esay test. Tes akan dilakukan sebanyak dua kali. Tes kemampuan awal sampel dilakukan sebelum perlakuan dan tes akhir (tes pemahaman konsep) dilakukan setelah perlakuan. Selisih nilai tes awal dan akhir digunakan untuk menguji hipotesis.

6. Validasi Instrumen Penelitian

Instrumen penelitian yang nantinya dipakai dalam kegiatan penelitian terlebih dahulu divalidasi dan validasi instrumen ini dilakukan oleh tim ahli

7. Analisis Data

Analisis data yang digunakan meliputi, uji prasyarat analisis, uji kesamaan kemampuan awal sampel dan uji hipotesis.

\section{Hasil dan Pembahasan}

\section{Uji Normalitas}

Setelah dilakukan uji normalitas, hasil yang diperoleh yakni; Untuk tes kemampuan awal siswa, kelas eksperimen diperoleh $\chi_{\text {hitung }}^{2}=2,67$ sedangkan $\chi_{\text {tabel }}^{2}=5,991$. Untuk kelas kontrol diperoleh $\quad \chi_{\text {hitung }}^{2}=3,47 \quad$ sedangkan $\chi_{\text {tabel }}^{2}=5,991$. Dengan demikian tes kemampuan 
awal siswa kelas eksperimen dan kelas kontrol menghasilkan $\chi_{\text {hitung }}^{2}<\chi_{\text {tabel }}^{2}$ maka dapat disimpulkan bahwa data hasil tes kemampuan awal siswa kelas eksperiman dan kelas kontrol terdistribusi normal (lampiran 4.1.1).

Pada tes kemampuan akhir atau tes pemahaman konsep fisika siswa kelas eksperimen diperoleh $\chi_{\text {hitumg }}^{2}=3,47 \quad$ sedangkan $\quad \chi_{\text {tabel }}^{2}=5,991$ sedangkan pada kelas kontrol diperoleh $\chi_{\text {hitumg }}^{2}=2,12 \quad$ sedangkan $\quad \chi_{\text {tabel }}^{2}=5,991$ (Lampiran 4.1.2). Dari nilai $\chi_{\text {hitung }}^{2}$ kelas eksperimen dan kelas kontrol yang lebih kecil dari $\chi_{\text {tabel }}^{2}$ maka dismpulkan bahwa data hasil tes kemampuan akhir atau tes pemahaman konsep fisika siswa terdistribusi normal.

\section{Uji Homogenitas}

Tes kemampuan awal, setalah dilakukan uji homogenitas diperoleh $\chi_{\text {hitumg }}^{2}=0,02142$ sedangkan $\chi_{\text {tab } \theta l}^{2}=3,84$. Ini memberikan pemahaman bahwa $\chi_{\text {hitumg }}^{2}<\chi_{\text {tabel }}^{2}$ dengan demikian disimpulkan bahwa populasi dalam penelitian ini mempunyai varians yang homogen (lampiran 4.1.3).

Untuk tes kemampuan akhir atau tes pemahaman konsep fisika siswa kelas eksperimen dan kelas kontrol diperoleh $\chi_{\text {hitung }}^{2}=0,03377$ sedangkan $\chi_{\text {tabel }}^{2}=3,84$. Ini memberikan pemahaman bahwa $\chi_{\text {hitmg }}^{2}<\chi_{\text {tabel }}^{2}$ dengan demikian disimpulkan bahwa populasi dalam penelitian ini mempunyai varians yang homogen (Lampran 4.1.4).

\section{Uji Kesamaan Kemampuan Awal Sampel}

Untuk uji kemampuan awal sampel digunakan uji kesamaan dua rata-rata (uji t) dengan uji dua pihak. Setelah data hasil tes dianalisis, diperoleh $\mathrm{t}_{\text {hitumg }}=0,40522045$ dan $t_{\text {tabel }}=1,9151$ dengan taraf signifikan $(\alpha)=0,05$ dengan derajat kebebasan $(\mathrm{dk})=36$. Karena $t_{\text {hitmg }}<\mathrm{t}_{\text {tab } \Theta l}$ maka disimpulkan bahwa hipotesis nol (H0) diterima dan hipotesis satu (H1) ditolak. Hal ini berarti bahwa tidak ada perbedaan kemampuan awal antara siswa kelas eksperimen dan kelas kontrol.

\section{Uji Hipotesis Penelitian}

Uji hipotesis penelitian digunakan uji kesamaan dua rata-rata (uji t). Hipotesis pertama digunakan uji t dua pihak, sedangkan untuk hipotesis kedua digunakan uji t satu pihak yaitu uji pihak kanan.

\section{Uji Hipotesis Pertama}

Setelah dilakukan analisis pada data hasil tes pemahaman konsep siswa diperoleh $\mathrm{t}_{\text {hitumg }}=4,968859$ dan $\mathrm{t}_{\text {tabel }}=1,9151$ dengan taraf signifikan $(\alpha)=0,05$ dan derajat kebebasan (dk) $=36 . \quad$ Oleh karena $\mathrm{t}_{\text {hitmg }}=4,968859>\mathrm{t}_{\text {tab }_{\ominus \mathrm{l}}}=1,9151 \quad$ maka disimpulkan bahwa hipotesis nol (H0) ditolak dan hipotesis satu (H1) diterima. Hal ini berarti terdapat perbedaan pemahaman konsep fisika yang signifikan antara kelas eksperimen atau siswa yang diajar dengan model pembelajaran perubahan konseptual dengan teknik analogi penghubung dan kelas kontrol atau siswa yang diajar dengan menggunakan model pembelajaran perubahan konseptual dengan teknik anomali. Hal ini disebabkan karena adanya perbedaan perlakuan dengan serangkaian dinamika pembelajaran yang terjadi pada kelas eksperimen dan kelas kontrol. Kelas eksperimen diterapkan model pembelajaran perubahan konseptual dengan teknik analogi penghubung. Pada kelas kontrol diterapkan model pembelajaran perubahan konseptual dengan teknik anomali. Dinamika Pembelajaran yang terjadi kelas eksperimen atau kelas yang diterapkan model pembelajaran perubahan konseptual dengan teknik analogi penghubung dalam proses pembelajran diawali dengan pengenalan masalah konseptual dan kontekstual, kemudian dilanjutkan dengan konfrontasi miskonsepsi yang ada dalam konsep terkait, setelah itu dupayakan adanya konflik kognitif dengan menggunakan pertanyaanpertanyaan terkait, dilanjutkan dengan pengenalan kasus anologi atau peristiwa lingkungan sekitar yang memiliki kemiripan sifat dengan konsep fisika yang dipelajari. Pemetaan atribut atau kegiatan membandingkan sifat dilakukan, selanjutnya dilakukan pengkajian atas batasan dan fungsi anologi dalam pembelajaran konsep fisika. Konfrontasi konsep yang telah diperoleh tehadap contoh kontekstual dilakukan pada tahap berikutnya dan diakhiri dengan konfrontasi pertanyaan terkait untuk perluasan pemahaman.

Dinamika Pembelajaran yang terjadi pada kelas kontrol atau kelas yang diterapkan model pembelajaran perubahan konseptual dengan teknik anomali dalam proses pembelajaran diawali dengan pengenalan masalah konseptual dan kontekstual, 
kemudian dilanjutkan dengan konfrontasi miskonsepsi yang ada dalam konsep terkait, Setelah itu dupayakan adanya konflik kognitif dengan menghadirkan kasus anomali. Peninjauan terhadap kasus anomali dilakukan dalam fase konfrontasi pembuktian konsep secara ilmiah. Selanjutnya konfrontasi konsep yang telah diperoleh tehadap contoh kontekstual dilakukan pada dan diakhiri dengan konfrontasi pertanyaan terkait untuk perluasan pemahaman

\section{Uji Hipotesis Kedua}

Setelah data hasil tes pemahaman konsep dianalisis diperoleh $t_{\text {hitms }}=4,968859$ dan $t_{\text {tabel }}=1,68026$ dengan taraf signifikan dan derajat kebebasan $(\mathrm{dk})=48$. Oleh karena $\mathrm{t}_{\text {hitmg }}=4,968859>\mathrm{t}_{\text {tab } \Theta \mathrm{l}}=1,68026$ maka dapat disimpulkan bahwa hipotesis nol (H0) ditolak dan hipotesis satu (H1) diterima. Hal ini berarti bahwa pemahaman konsep fisika siswa kelas eksperimen atau siswa yang diajar menggunakan model pembelajaran perubahan konseptual dengan teknik analogi penghubung, lebih tinggi dibandingkan dengan pemahaman konsep fisika siswa kelas kontrol atau siswa yang diajar menggunakan model pembelajaran perubahan konseptual dengan teknik anomali. Pembelajaran dilakukan dengan diterapkannya model pembelajaran perubahan konseptual dengan teknik yang berbeda pada kelas kontrol dan kelas eksperimen. Karakteristik perlakuan nampak pada fase ketiga dan keempat dari model pembelajaran perubahan konseptual yang diterapkan pada kelas eksperimen dan kelas kontrol. Pada kedua fase tersebut kental atau nampak akan warna teknik yang digunakan yakni teknik analogi penghubung pada kelas eksperimen dan teknik anomali pada kelas kontrol. sehingga memberikan Dampaknya terhadap pembelajaran baik pada kelas eksperimen maupun kelas kontrol.

Pada kelas eksperimen kegiatan yang berlangsung yakni siswa terlebih dahulu diperkenalkan tentang topik materi yang akan dipelajari. Selanjutnya siswa dibimbing untuk menemukan permasalahan atau fenomena kontekstual yang berkaitan dengan materi yang dipelajari. Pada tahapan ini siswa secara antusias menyebutkan secara intuitif peristiwa yang menurutnya berkaitan dengan materi yang dipelajari. Setelah gagasan siswa didengar, siswa lalu dikonfrontir melalui beberapa pertanyaan dengan tujuan untuk mengetahui respons sebagai imbas dari adanya konflik koognitif dalam diri siswa. Pada tahapan ini siswa menjelaskan gagasan atau idenya tentang kaitan antara masalah keseharian yang disebutkan dengan materi yang dipelajari.

Gagasan yang dipaparkan siswa sebagai respons, siswa kemudian diperkenalkan kasus analogi dan anlogi penghubung. Setelah siswa diperkenalkan kasus analogi dan anlogi penghubung, siswa kemudian dibimbing untuk membuat perbandingan antara konsep dan analog atau melakukan pemetaan atribut. Tahapan ini diawali dengan siswa terlebih dahulu dibentuk dalam kelompok dengan tiap kelompok terdiri dari 4 sampai 5 orang. Setelah siswa berada dalam kelompok, pemetaan atribut atau kegiatan membandingkan kasus analogi dengan materi yang dipelajari dengan bimbingan guru diadakan. Siswa secara antusias berdiskusi secara aktif menemukan sifat- sifat dalam kasus analogi yang memiliki kemiripan dengan sifat konsep yang secara sepintas disampaikan guru. Setiap jawaban siswa disajikan dalam lembar kerja siswa yang diberikan peneliti.

Pada tahapan ini terlihat sebuah proses penemuan konsep, dimana konsep yang awalnya sulit dipahami, dimediasi secara baik untuk masuk kedalam struktur kognitif siswa dengan dikatalisasi oleh kasus analogi yang ditinjau. Sehingga siswa dengan mudah menerima dan memahami konsep yang dipelajari. Selanjutnya untuk memberikan penegasan agar tidak terjadi miskonsepsi pada struktur kognitif siswa, guru membimbing siswa mengkaji atau menemukan batasan analogi tujuannya untuk membantu siswa membedakan konsep dengan analogi dan menumbuhkan sikap bahwa anlogi hanya berfungsi sebagai media jalan masuknya konsep ilmiah. Hal ini direspon siswa dengan secara aktif menemukan batasan-batasan analogi yang kemudian disampaikan secara klasikal.

Konsep yang telah diperoleh saat pemetaan atribut tadi dipakai siswa untuk menjelaskan masalah kontekstual yang dipaparkanya diawal pembelajaran. Tampak bagaimana siswa secara spontan mengemukakan pendapat untuk mengaitkan dan menggolongkan fenomenafenomena tersebut yang berkaitan dengan materi ajar. Selanjutnya siswa diperhadapkan lagi dengan konfrontasi pertanyaan dengan maksud untuk memperluas pemahaman siswa tentang materi yang dipelajari. Pada tahapan ini berbekal konsep yang 
telah ditemukan, siswa memberikan jawaban sebagai respons atas pertanyaan guru setiap jawaban siswa terlihat memiliki rel konsep yang baik dan telah mampu membuat pengembangan pemahaman untuk menjawab pertanyaanpertanyaan yang disajikan guru. Tahapan ini dilakukan dalam dua fase yakni fese pertama pada kuis yang diberikan dan fase kedua pada saat penekanan konsep.

\section{Kesimpulan}

Berdasarkan hasil analisis data dan pembahasan hasil penelitian, maka dapat disimpulkan bahwa:

Ada perbedaan pemahaman konsep fisika yang signifikan antara siswa yang diajar menggunakan penerapan model pembelajaran perubahan konseptual dengan teknik analogi penghubung, dengan siswa yang diajar dengan menggunakan penerapan model pembelajaran perubahan konseptual dengan teknik anomali.

Pemahaman konsep fisika siswa yang diajar menggunakan model pembelajaran perubahan konseptual dengan teknik analogi penghubung lebih tinggi daripada siswa yang diajar menggunakan model pembelajaran perubahan konseptual dengan teknik anomali

\section{Daftar Pustaka}

Harrison., Richard., dan Coll. 2013. Analogi Dalam Kelas Sains. Jakarta : PT Indeks

Boy H. 2014. Penerapan Model Pembelajaran ASSURE dengan Teknik Scramble Untuk meningkatkan Prestasi Belajar Fisika Siswa Kelas VIII SMP Swasta Diakui Adhyaksa 2 Kupang, Tugas akhir tidak dipublkikasikan, program studi Pendidikan Fisika Jurusan Pendidikan MIPA Fakultas Keguruan Dan ilmu Pendidikan Universitas Nusa Cendana

Kesumawati N. 2008. Pemahaman Konsep Matematika Dalam Pembelajaan Matematika. FKIP Program Studi Matematika Universitas PGRI Palembang. Tugas Akhir Dipublikasikan.

Kusdian K. 2009. Pengaruh Metode Perubahan Konseptual (conceptual Mehods) dalam seting Model 5E Terhadap Pemahaman Konsep Siswa SMA Lab Undiksha Singaraja. http://www.slideshare.net/koess/model-5-e. 15 november 2013
Lein Y. T. 2012. Penerapan Model Pembelajaran Based Intruction Sebagai Upaya Untuk Meningkatkan Pemahaman Konsep Gerak Melingkar Pada Siswa Kelas X SMA Negeri 1 Kupang Tahun Ajaran 2012/2013. Tugas Akhir Tidak Diplubikasikan, Program Studi Pendidikan FKIP Universitas Nusa Cendana Kupang.

Prasetyarini A. 2013. Pemanfaatan Alat Peraga Untuk Meingkatkan Pemahaman Konsep Siswa SMP Negeri 1 Bulus Pesantren Kebumen. Program Studi Pendidikan Fisika Universitas Muhamadiayah Purworejo.

Santyasa I. W. 2007. Model-Model Pembelajaran Inovatif. Makalah disajikan pada pelatihan guru-guru SMP dan SMA. Nusa Penida Bali. Tanggal 27 Juni 2007.

2008. Pengembanagan Pemanfaatan

Konsep Dan Kemampuan Pemecahan Masalah Siswa SMA Dengan Pemberdayaan Model Perubahan Konseptual. Berseting Investigasi Kelompok. Lembaga Penilitian universitas Pendidikan Genesa.

Soko I. P. 2009. Penggunaan Animasi Dalam Pembelajaran Untuk Meningkatkan Motivasi Belajar Dan Pemahaman Konsep Fisika Siswa SMA Negeri 3 Kupang. Tugas akhir tidak dipublikasikan. Program studi pendidikan Fisika, jurusan pendidikan MIPA, FKIP, Universitas Nusa Cendana Kupang.

Suparno P. 2007. Metodologi Pembelajaran Fisika Konstruktivistik dan Menyenagkan. Yogyakarta: Universitas Sanata Darma 2013. Miskonsepsi dan Perubahan konseptual dalam pendidikan Fisika. Jakarta : Gramedia Widia Sarana Indonesia.

Tadas M. B. 2014. Integrasi Model Children Learning In Science (CLIS) Dengan Model Examples Non Examples Dalam Meningkatkan Pemahaman Konsep Siswa SMP Negeri 2 Kupang, Tugas Akhir Tidak Dipublikasi, Program studi Pendidikan Fisika, Jurusan Pendidikan MIPA, FKIP, Universitas Nusa Cendana Kupang.

Tafuli D. 2013 Penerapan Model Pembelajaran Learning Cycle 7 E Dengan Media Mind Mapping Untuk Meningkatkan Keterampilan Generik Sains Siswa Kelas X SMP Negeri 10 Kupang. Tugas akhir tidak dipublkikasikan, program studi Pendidikan Fisika Jurusan 
Pendidikan MIPA Fakultas Keguruan Dan ilmu Pendidikan Universitas Nusa Cendana.

Zega D. S. 2013. Model Pembelajaran Perubahan Konseptual.

http://yudistiadewisilvia.wordpress.com/2013 /03/12/model-pembelajaran-perubahankonseptual/comment-page-1/. 19 November 2013 